М. А. Куприна, М. А. Гайдаманова, Т. М. Лысикова. Успешные практики наставничества молодых педагогов в школьном образовательном пространстве

Научная статья

УДК 371.15

DOI: $10.18101 / 2307-3330-2021-3-21-26$

\title{
УСПЕШНЫЕ ПРАКТИКИ НАСТАВНИЧЕСТВА МОЛОДЫХ ПЕДАГОГОВ В ШКОЛЬНОМ ОБРАЗОВАТЕЛЬНОМ ПРОСТРАНСТВЕ
}

\author{
(C) Куприна Марина Александровна \\ директор, учитель физики, \\ Средняя общеобразовательная школа № 588 \\ Россия, 196655, г. Санкт-Петербург, ул. Тверская, 54, корп. 2А \\ marinakuprina@mail.ru
}

(C) Гайдаманова Марина Анатольевна

методист, учитель экономики,

Средняя общеобразовательная школа № 588,

Россия, 196655, г. Санкт-Петербург, ул. Тверская, 54, корп. 2А

strokh@mail.ru

\section{(C) Лысикова Татьяна Михайловна}

заместитель директора по УВР, учитель английского языка, Средняя общеобразовательная школа № 588

Россия, 196655, г. Санкт-Петербург, ул. Тверская, 54, корп. 2А

indian-summer@mail.ru

Аннотация. В статье обобщен опыт пилотной школы по апробации практик наставничества молодых педагогов, результаты реализации которых позволили отнести их к категории успешных.

Особое место уделено факторам, определившим появление данных форм наставничества, описанию действенных форм работы, ролевому репертуару наставника и наставляемых, достигнутым эффектам сотрудничества.

Реализованная в рамках Методического клуба по финансовой грамотности практика «Финансовый наставник» позволила выявить не только дефициты молодого педагога, но и определить действенные инструменты наставничества. Такое взаимодействие потребовало от наставника и смены ролевой позиции.

Авторы описывают модель реализации практики наставничества «Инженер настоящего - инженеру будущего», интегрирующую помимо стандартных этапов реализации целевой модели проектную стадию, позволяющую школьникам выполнять реальный заказ работодателя.

Ключевые слова: целевая модель наставничества, практики наставничества, Методический клуб по финансовой грамотности, социальная дезориентация старшеклассников, групповой проект, ролевой репертуар наставника и наставляемого, эффекты реализации практик.

\section{Для цитирования}

Куприна М. А., Гайдаманова М. А., Лысикова Т. М. Успешные практики наставничества молодых педагогов в школьном образовательном пространстве // Вестник Бу- 
рятского государственного университета. Образование. Личность. Общество. 2021. № 3. С. 21-26.

Участие школы в пилотном проекте по внедрению целевой модели наставничества в Санкт-Петербурге в 2020/21 учебном году инициировало поиск и наполнение традиционной наставнической деятельности новыми форматами работы по профессиональной адаптации молодых педагогов в школьном образовательном пространстве. Разработанная программа наставничества запустила процесс апробации двух практик: «Финансовый наставник» и «Инженер настоящего — инженеру будущего», результаты реализации которых позволили отнести их к числу эффективных.

Одной из форм взаимодействия педагогов сегодняшнего дня, способствующих удовлетворению их естественного стремления к раскрытию личностной позиции, саморазвитию и самореализации, является клубная форма профессиональных объединений. В целях реализации мероприятий по формированию финансовой грамотности осенью 2019 г. по инициативе учителей на площадке школы был создан Методический клуб по финансовой грамотности как постоянно действующее неформальное объединение заинтересованных коллег. С одной стороны, это возможность самовыражения и ресурс профессионального роста для молодых педагогов, а с другой, разрешение сомнений в верности выбранных методов и педагогических находок в процессе обсуждения с опытными коллегами. Деятельность клуба выявила не только проблемные поля молодых педагогов сообщества, но и подсказала, какие инструменты следует использовать для наставничества. Была выбрана ролевая модель «мастер - новичок» (форма «учитель - учитель») с целью поддержки начинающих специалистов вне зависимости от предметной направленности, приобретения ими необходимых профессиональных навыков и личностных компетенций.

Проведенный опрос подтвердил целесообразность создания наставнической пары в рамках тематики клуба, поскольку, с одной стороны, современные молодые педагоги подтвердили потребность в динамичной адаптации и самореализации. С другой, суммарно 87,5\% респондентов на вопрос: «Удовлетворяет ли вас уровень профессиональной подготовки по «финансовой грамотности?» — дали ответы «нет» и «не в полной мере». Показательно, что при ответе на вопрос: «Каким формам повышения квалификации Вы отдаете предпочтение?» - новички не выбрали традиционные курсы повышения квалификации. Среди самых популярных ответов выбраны: участие в мастер-классах (62\%), участие в практико-ориентированных семинарах (12\%), самообразование (12,5\%). А в качестве проблем обозначены типичные для стартующих в педагогике затруднения:

1) с чего начать внедрение в учебный процесс - $27 \%$;

2) мотивация и активизация деятельности учащихся $-21 \%$;

3) ориентация в современных образовательных технологиях и подбор соответствующих методов и приемов - $13 \%$;

4) отсутствие информации об образовательных ресурсах - $11 \%$,

5) отсутствие пособий в школе - 9\%;

6) организация сотрудничества между учащимися - $9 \%$;

7) боязнь неудачи при освоении нового направления деятельности $-6 \%$; 
М. А. Куприна, М. А. Гайдаманова, Т. М. Лысикова. Успешные практики наставничества молодых педагогов в школьном образовательном пространстве

8) недостаточный уровень математической грамотности - 4\%.

Важнейшим фактором успешности тандема «Финансовый наставник» является личность самого наставника. Какими бы ни были формы и методы работы опытного коллеги, начиная от коллективного просмотра мультфильмов и разбора региональных работ по функциональной грамотности до сопровождения индивидуальных проектов старшеклассников, проактивность, позитивное мышление и развитая эмпатия являются ориентирами для роста наставляемого. Однако взаимодействие в данных условиях потребовало и от наставника не только использования разнообразного арсенала практикоориентированных форм профессионального развития педагогов, но и смены самих позиций. Параллельно развивалось незаявленное первоначально сотрудничество «современный - опытному», когда обладающий современными навыками работы с информацией молодой учитель помогал своему опытному партнеру овладеть цифровыми навыками и технологиями для решения общих содержательных задач. В числе успешно реализованных форматов сотрудничества наставника и наставляемого совместное проектирование и проведение внеурочных занятий по финансовой грамотности, разработка и апробация элементов урочной деятельности, включение модулей по финансовой грамотности в рабочую программу по предмету, разработка методических материалов для городского конкурса методических разработок по финансовой грамотности, организация и проведение районного чемпионата по финансовой грамотности в рамках II Всероссийского чемпионата по финансовой грамотности, подготовка учащихся к успешному выступлению на чемпионате и олимпиаде по финансовой грамотности, проведение разноаспектных заседаний Методического клуба и районных семинаров.

Определяющим результатом такой формы наставничества следует считать не объем информации, а изменения, которые предполагают положительную динамику профессионального роста наставляемого, его «закрепление» в предметном и данном тематическом направлении, включенность в образовательные процессы школы, а также участие в исследовательской, проектной, олимпиадной деятельности.

Очевидными показателями успешности практики наставничества являются рост показателей удовлетворенности молодого педагога результатами профессиональной деятельности, качественный рост показателей гибких навыков и личностных компетенций наставляемого. Дополнительным эффектом стала реализованная потребность «новичка» в поиске и начале разработки «своей методической темы» «финансовая психология» в рамках Методического клуба.

Вторая из успешно реализованных практик «Инженер настоящего - инженеру будущего» ориентирована на решение назревших проблем и ликвидацию дефицитов образовательной практики школы, в числе которых, с одной стороны, проблема социальной дезориентации старшеклассников, выражающаяся в неспособности профессионально-образовательного самоопределения в приоритетных для экономики сферах, к которым относится подготовка будущих инженеров, а с другой - проблема закрепления в профессии и школе молодого специалиста.

С учетом образовательных специфики школы, запросов наставляемого и ресурсов наставника сложился вариант ролевой модели «научный сотрудник - учительпрактик» в рамках предложенной программой наставничества формы «работода- 
тель - учитель». В качестве инструмента для замещения дефицитных компетенций администрацией школы было принято решение о соединении раздельно существующих практик наставничества и проектной деятельности старшеклассников.

В школьной Программе наставничества молодой педагог определен как испытывающий затруднения в реализации профориентационной компоненты в рамках своей предметной области, не имеющий опыта (достаточной ресурсной базы) для отработки практических навыков обучающихся, не обладающий достаточным набором компетенций в определенной узкой профессиональной сфере, вызывающей интерес у обучающихся наставляемый.

Целью такой формы наставничества является развитие личностного потенциала (включая научный и творческий) как условия успешности ученика. Данный формат предусматривает получение педагогом опыта совместной с наставником (и обучающимися профильных классов) в проектной, олимпиадной, чемпионатной и конкурсной деятельности, профессиональных проб, занятий в лабораториях и мастерских. Ожидаемый результат реализации - актуализация педагогом метапредметных компетенций, расширение диапазона прикладных предметных навыков, необходимых для сопровождения профориентационного самоопределения обучающихся.

Разработанная модель реализации практики наставничества «Инженер настоящего - инженеру будущего» интегрирует, помимо стандартных этапов реализации целевой модели наставничества, проектную стадию, позволяющую школьникам выполнять реальный заказ работодателя. Таким образом, в рамках представленной практики реализуется групповой проект «Проектирование оснастки, оптимизирующей процесс изготовления компонентов для международного проекта ITER», который является инструментом профессионального самоопределения и развития профессиональной инженерной ориентации команды. В состав команды вошли наставляемые - четверо учащихся профильного технологического класса вместе с заинтересованным в профессиональном развитии молодым учителем физики, преподающим предмет «Индивидуальный проект», и «наставник-работодатель», инженерконструктор АО «НИИЭФА им. Д. В. Ефремова» Госкорпорация «Росатом».

Практика выстроена по четырем укрупненным стадиям реализации: подготовительной, отборочно-обучающей, проектной и рефлексивной, внутри которых последовательно встроены и реализуются основные этапы целевой модели наставничества с учетом обозначенных в ней принципов и правил. Результатом проектной стадии является цифровой прототип промышленного изделия, спроектированный в среде 3D-моделирования. На данной стадии группа наставляемых проживает жизненный цикл проекта от этапа формулировки концепции до этапа внедрения, позволяющий снять психологические барьеры «на вход» в профессию.

В период выполнения командной проектной работы по созданию основания для размещения и перемещения изделия (вакуумного чехла) команда наставляемых вместе с педагогом последовательно выполняла задачи:

- знакомство с атомной отраслью и профессиями будущего;

- освоение программы Autodesk Inventor - системы трехмерного твердотельного и поверхностного параметрического проектирования, предназначенной для создания цифровых прототипов промышленных изделий; 
М. А. Куприна, М. А. Гайдаманова, Т. М. Лысикова. Успешные практики наставничества молодых педагогов в школьном образовательном пространстве

- обучение в онлайн-лаборатории Академии Росатома «Junior AtomSkills» по компетенции «Инженерный дизайн CAD»;

- знакомство с конструктивными особенностями изделия;

- изучение физических характеристик изделия;

- создание эскизных чертежей и подбор соответствующих материалов;

- проектирование каждой трехмерной детали изделия;

- создание трехмерной сборки оснастки;

- анализ конструктивных неточностей и устранение ошибок при сборке;

- презентация 3D-модели для прочностных расчетов работодателю;

- посещение предприятия с целью знакомства с возможностью использования результатов проектной деятельности.

В предлагаемом формате наставничества важно всем участникам четко соблюсти «правила игры», обозначенные целевой моделью наставничества, чтобы не только достичь запланированных показателей, но и не навредить, поскольку групповое проектное наставничество - еще более сложный формат взаимодействия участников, чем парный. В связи с этим возникла необходимость четкого разграничения ролей работодателя-наставника и наставляемого-учителя. Роль учителя особая. С одной стороны, он равноценный член группы наставляемых, который вместе с учениками обучается в лаборатории, изучает азы работы в конструкторской программе, а с другой - посредник, фасилитатор, обеспечивающий комфортность процесса коммуникаций для всех участников. Ролевой репертуар работодателянаставника разнообразнее, сложнее (таблица 1).

Роли субъектов практики

Таблий 1

«Инженер настоящего — инженеру будущего» на этапах проектного цикла

\begin{tabular}{|c|c|c|}
\hline \multirow{2}{*}{$\begin{array}{l}\text { Этапы проектного } \\
\text { цикла }\end{array}$} & Работодатель & Учитель \\
\hline & \multicolumn{2}{|c|}{ Ролевой репертуар } \\
\hline Концепция & Коуч, куратор & Фасилитатор \\
\hline Разработка & Куратор, ментор & Фасилитатор, эдвайзер \\
\hline Тестирование & Эксперт & Фасилитатор \\
\hline Внедрение & $\begin{array}{l}\text { Заказчик } \\
\text { Эксперт }\end{array}$ & $\begin{array}{l}\text { Фасилитатор } \\
\text { Эксперт (защита) }\end{array}$ \\
\hline Эксплуатация & Заказчик & Фасилитатор, психолог \\
\hline
\end{tabular}

Мониторинг «на выходе» зафиксировал в числе достигнутых эффектов реализации практики сокращение срока адаптации молодого педагога, рост показателей его профессионального развития, расширение границ прикладного предметного знания, формирование мотивации на дальнейшее участие в программе наставничества и конкурсах профессионального мастерства. Достижение целевых показателей практики позволяет включить ее в базу лучших практики наставничества и рекомендовать к тиражированию.

Необходимо отметить, что результаты апробации представленных практик наставничества молодых педагогов продемонстрировали их востребованность. Они 
представлены на районном фестивале лучших практик наставничества, в городских конкурсах «Лучшая инклюзивная школа 2021 г.», лучших практиках реализации программ наставничества «Вперед и вместе».

Высокая эффективность предполагает их использование как ресурс профессионального развития молодых педагогов не только в рамках школьного образовательного пространства, но и в городской системе образования.

Статья поступила в редакичю 18.11.2021; одобрена после рецензирования 22.11.2021; принята к публикациии 07.12.2021.

\section{SUCCESSFUL MENTORING PRACTICES OF YOUNG TEACHERS IN THE SCHOOL EDUCATIONAL SPACE}

\section{Marina A. Kuprina}

director, physics teacher

Secondary school $\# 588$ of St. Petersburg

54, building 2, letter A, Tverskaya street, Kolpinskiy district, St. Petersburg, 196655 Russia

\section{Marina A. Gaidamanova}

methodologist, teacher of economics

Secondary school \#588 of St. Petersburg

54, building 2, letter A, Tverskaya street, Kolpinsky district, St. Petersburg, 196655 Russia

Tatiana M. Lysikova

Deputy Director, English teacher

Secondary school $\# 588$ of St. Petersburg

54, building 2, letter A, Tverskaya street, Kolpinsky district, St. Petersburg, 196655 Russia

This article summarizes the pilot school experience of testing the practices of mentoring young teachers which were recognized successful.

Special attention is paid to the factors that determined the emergence of these forms of mentoring, the description of effective forms of work, the role repertoire of the mentor and the mentored, the achieved effects of cooperation.

The "Financial Mentor" practice, implemented within the framework of the Methodological Club on Financial Literacy, made it possible to identify not only the deficiencies of a young teacher, but also effective mentoring tools. This interaction made mentor change the role position. The authors describe a model for the implementation of mentoring practice "An engineer of the present to an engineer of the future", which integrates standard stages of implementing the target model, and the project stage, which allows schoolchildren to fulfill the real order of the employer. Keywords: target model of mentoring, mentoring practices, Methodological club on financial literacy, high school children social disorientation, group project, role repertoire of a mentor and mentored, effects of practice implementation.

The article was submitted 18.11.2021; approved after reviewing 22.11.2021; accepted for publication 07.12.2021. 